University of Nebraska - Lincoln

DigitalCommons@University of Nebraska - Lincoln

Roman L. Hruska U.S. Meat Animal Research

U.S. Department of Agriculture: Agricultural Center

Research Service, Lincoln, Nebraska

2005

\title{
Genetic Relationships Between Male and Female Reproductive Traits in Beef Cattle
}

\author{
G. Gargantini \\ University of Nebraska, Lincoln
}

L. V. Cundiff

University of Nebraska, Lincoln, Larry.Cundiff@ars.usda.gov

D. D. Lunstra

ARS, USDA, USU.S. Meat Animal Research Center, Clay Center, NE

L. D. Van Vleck

ARS, USDA, USU.S. Meat Animal Research Center, Lincoln, NE

Follow this and additional works at: https://digitalcommons.unl.edu/hruskareports

Part of the Animal Sciences Commons

Gargantini, G.; Cundiff, L. V.; Lunstra, D. D.; and Van Vleck, L. D., "Genetic Relationships Between Male and Female Reproductive Traits in Beef Cattle" (2005). Roman L. Hruska U.S. Meat Animal Research Center. 168.

https://digitalcommons.unl.edu/hruskareports/168

This Article is brought to you for free and open access by the U.S. Department of Agriculture: Agricultural Research Service, Lincoln, Nebraska at DigitalCommons@University of Nebraska - Lincoln. It has been accepted for inclusion in Roman L. Hruska U.S. Meat Animal Research Center by an authorized administrator of DigitalCommons@University of Nebraska - Lincoln. 


\title{
Crin \\ Genetic Relationships Between Male and Female Reproductive Traits in Beef Cattle
}

\author{
G. GARGANTINI*,2, L. V. CUNDIFF*, D. D. LUNSTRA ${ }^{\dagger}$, and L. D. VAN VLECK ${ }^{\ddagger 3}$ \\ *University of Nebraska, Lincoln 68583-0908; ${ }^{\dagger}$ ARS, USDA, USMARC, Clay Center, NE 68933; ${ }^{\ddagger}$ ARS, \\ USDA, USMARC, Lincoln, NE 68583-0908
}

\section{Abstract}

Reproductive traits were measured for 234 bulls and 1184 heifers from matings of three dam breeds (Angus, Hereford, and MARC III) with six sire breeds (Angus, Hereford, Brahman, Boran, Tuli, and Belgian Blue) from the Germ Plasm Evaluation (GPE) Program at Roman L. Hruska US Meat Animal Research Center. Male traits were yearling scrotal circumference (YSC), height (YH), and yearling $B W$; age at puberty (AP1; production of 50 million sperm with $\geq 10 \%$ progressive motility); age, scrotal circumference, average testis length, and testicular volume when 500 million sperm were produced with $\geq 50 \%$ progressive motility $(A P 3, S C 3, L 3$ and $V 3$, respectively); and 15-mo BW (15W) and height $(\mathbf{1 5 H})$. Traits of females were age at puberty (AP, first estrus) and pregnancy rate (PR) at $18 \mathrm{mo}$. The objective was to determine whether indirect selection on male traits would be effective for improving female fertility traits. Selection of males on AP1, AP3, SC3, L3, V3, $Y H, 15 \mathrm{~W}$, and $15 \mathrm{H}$ may be useful for

\footnotetext{
${ }^{1}$ Published as paper no. 14841, Journal Series, Nebraska Agric. Res. Div., Univ. of Nebraska, Lincoln 68583-0908.

${ }^{2}$ Current address: University of Nebraska, Lincoln 68583-0908.

${ }^{3}$ To whom correspondence should be addressed: Ivanvleck@unlnotes.unl.edu
}

improving PR because of genetic correlations and low heritability for PR. Although no male trait was found to be effective for improving AP in females through indirect selection, YSC and SC3 were the most favorable. If heritability were as large as estimated in this study for $A P(0.52)$, direct rather than indirect selection would seem to be more effective for AP in heifers, although the difficulty of measuring $A P$ in heifers also would need to be considered. Male reproductive traits, such as scrotal circumference and also $\mathrm{YH}$ and $15 \mathrm{H}$, however, are easier and less expensive to measure than female reproductive traits, and greater selection intensity can be applied to these male traits.

(Key Words: Beef Cattle, Fertility, Growth, Selection.)

\section{Introduction}

For segments of the industry that try to calve heifers at $2 \mathrm{yr}$ of age, much of the success of a beef cowcalf enterprise will depend on having heifers calve at 2 yr of age and to rebreed shortly after first calving. Therefore, for such producers, selection for improving heifer genetic potential for fertility will be important (Doyle et al., 2000). Based on possible selection intensity for males and possibly greater heritabilities, selection for reproductive traits of males might be more effective than selection directly on female reproductive traits. The objective of this study was to investigate whether indirect selection might be more effective than direct selection for improvement of age at puberty and heifer pregnancy rate (PR) of heifers.

\section{Materials and Methods}

Data were from Cycle V of the Germ Plasm Evaluation (GPE) at the Roman L. Hruska US Meat Animal Research Center (Clay Center, NE). The base cow-herd for Cycle V involved about 500 Angus, 350 Hereford, and 550 MARC III composite (1/4 Angus, $1 / 4$ Hereford, $1 / 4$ Pinzgauer, and $1 / 4$ Red Poll) cows. These cows were mated to six sire breeds: Angus, Hereford, Brahman, Boran, Tuli, and Belgian Blue for 3 yr (1992, 1993, and 1994). Angus sires were bred to Hereford and MARC III cows, and Hereford sires were bred to Angus and MARC III cows. All other sire breeds were bred to Angus, Hereford, and MARC III cows. All cows were $4 \mathrm{yr}$ of age or older. The total number of bull and heifer calves by sire by dam breed combination is shown in Table 1 . Each year, a sample of about 80 male calves and about 400 female calves was evaluated for growth and pubertal development. 
TABLE 1. Number of male and female cattle in the analyses by breed of sire and breed of dam and number of sires by breed ${ }^{\mathrm{a}}$.

\begin{tabular}{|c|c|c|c|c|c|c|c|}
\hline \multirow[b]{3}{*}{ Sire breed } & \multirow{3}{*}{$\begin{array}{l}\text { Sires } \\
\text { (no.) }\end{array}$} & \multicolumn{6}{|c|}{ Dam breed } \\
\hline & & \multicolumn{2}{|c|}{ Hereford } & \multicolumn{2}{|c|}{ Angus } & \multicolumn{2}{|c|}{ MARC III } \\
\hline & & Male & Female & Male & Female & Male & Female \\
\hline Hereford & 31 & - & - & 18 & 65 & 14 & 87 \\
\hline Angus & 41 & 8 & 28 & - & - & 17 & 103 \\
\hline Brahman & 45 & 9 & 36 & 16 & 64 & 22 & 112 \\
\hline Boran & 8 & 9 & 33 & 15 & 73 & 19 & 100 \\
\hline Tuli & 9 & 10 & 34 & 14 & 77 & 29 & 133 \\
\hline Belgian Blue & 25 & 11 & 26 & 15 & 79 & 18 & 132 \\
\hline
\end{tabular}

${ }^{\mathrm{a}}$ Number sires per breed.

Calves were born between mid March and mid May each year. Calves were creep-fed whole oats from mid July until weaning in early October. Bull calves were weaned at about $185 \mathrm{~d}$ of age. Following weaning each year, samples of about 80 bull calves were randomly assigned to two drylot pens of approximately 40 bulls each with all sire and dam breeds represented in each pen. The calves were fed a diet of corn silage, rolled corn, and protein-mineral-vitamin supplement $(2.69 \mathrm{Mcal}$ of $\mathrm{ME} / \mathrm{kg}$ of DM; $12.88 \% \mathrm{CP}$ ) for 9 mo.

After weaning and a 42-d adjustment period, the sample of heifers was assigned to two pens per sire breed (Hereford- and Angus-sired females were treated as a single sire breed). Heifers were weighed when assigned to their treatment groups and then every $28 \mathrm{~d}$ until moved from drylot to pasture. The heifers were subsequently weighed at the beginning and end of the breeding season. Heifers were palpated approximately $65 \mathrm{~d}$ following the end of the breeding season to determine PR. Age at puberty was defined as the date of first observed standing estrus. Females were checked visually twice daily for estrus beginning on February 1 through the end of the breeding season.

For the bulls, BW, hip height, and scrotal circumference were measured at 28-d intervals. Puberty was defined as the age when a bull first produced an ejaculate containing at least $50 \times$ $10^{6}$ sperm with $\geq 10 \%$ progressive motility (Lunstra et al., 1978). All bulls reached puberty when scrotal circumference was between 30 and $32.5 \mathrm{~cm}$. Age at first freezable semen was defined as the age when a bull first produced an ejaculate containing at least $500 \times 10^{6}$ sperm with $\geq 50 \%$ progressive motility (Lunstra et al., 1993). Semen collection ceased for a bull when his ejaculate contained at least $500 \times 10^{6}$ sperm with $\geq 50 \%$ progressive motility.

Records for a total of $234 \mathrm{~F}_{1}$ bulls and $1184 \mathrm{~F}_{1}$ heifers were evaluated. Means, ranges, and phenotypic variances for growth and fertility traits are summarized in Table 2.

Estimates of genetic parameters were obtained using MTDFREML (Boldman et. al., 1995). Traits analyzed for males were yearling height (YH), yearling scrotal circumference (YSC), 15-mo BW (15W), 15-mo scrotal circumference (15SC), age at puberty (AP1), and age (AP3), scrotal circumference (SC3), average testis length (L3), and testicular volume (V3) when a bull first produced freezable semen. Traits analyzed for females were age at puberty (AP) and PR at palpation. To minimize density of the estimating equations and to account for possible interactions, the model included interactions between year and month of birth, and be- tween age of dam and line (breed group) of the animal as fixed effects; random effects included animal direct genetic, dam-maternal (sum of genetic plus permanent environmental), and residual effects.

Expected responses to direct and indirect selection were calculated for pairs of growth and reproductive traits in both males (M) and females (F) as described by Toelle and Robison (1985) using estimates of (co)variance components from the data. The selection intensity factor for males times one-half (one generation away) used for males $\left(1 / 2 \mathrm{i}_{\mathrm{M}}\right)$ was twice the magnitude of the direct selection intensity factor used for females, $\mathrm{i}_{\mathrm{F}}=$ $0.482\left(1 / 2 \mathrm{i}_{\mathrm{M}}=2 \mathrm{i}_{\mathrm{F}}\right)$. These intensity factors correspond approximately to selection of the best 7 and $70 \%$ of males and females, respectively. Efficiency of direct and indirect selection was compared using the ratio $(\mathrm{Q})$ of expected response to direct selection on the female trait $\left(\Delta \mathrm{G}_{\mathrm{F} . \mathrm{F}}\right)$ and to indirect selection on the male trait $\left(\Delta \mathrm{G}_{\mathrm{F} . \mathrm{M}}\right)$. Expected responses were based on individual performance using the formulas of Falconer and Mackay (1996): $\Delta \mathrm{G}_{\mathrm{F} . \mathrm{M}}=0.5 \mathrm{i}_{\mathrm{M}} \mathrm{h}_{\mathrm{F}} \mathrm{h}_{\mathrm{M}}$ $\mathrm{r}_{\mathrm{gF} g \mathrm{gM} \sigma \mathrm{PF}}$ and $\Delta \mathrm{G}_{\mathrm{F} . \mathrm{F}}=\mathrm{i}_{\mathrm{F}} \mathrm{h}_{\mathrm{F} \sigma \mathrm{PF}}^{2}$, where $\sigma \mathrm{PF}=$ phenotypic standard deviation for the female reproductive trait, $\mathrm{h}_{\mathrm{F}}$ and $h_{M}=$ square roots of the heritabilities of the female and male traits, and $\mathrm{r}_{\mathrm{gF}} \mathrm{gM}=$ genetic correlation between the male and female traits. The ratio of responses to indirect and direct selection was computed as $\mathrm{Q}=$ $\Delta \mathrm{G}_{\mathrm{F} . \mathrm{M}} / \Delta \mathrm{G}_{\mathrm{F} . \mathrm{F}}$. If $\mathrm{Q}$ was $>1$, indirect selection would be expected to be more effective than direct selection.

\section{Results and Discussion}

Estimates of heritability and genetic correlations among growth and reproductive traits are presented in Tables $3,4,5$, and 6 . Heritability estimates for growth were moderate to high; estimates for male yearling BW, $15 \mathrm{~W}$, $\mathrm{SC} 3$, and V3 were near unity probably because of the relatively small sample size. The heritability estimate for $\mathrm{YH}$ in males was low $(0.20)$. 
TABLE 2. Estimates of phenotypic variances and unadjusted means and ranges for growth and fertility traits ${ }^{a}$.

\begin{tabular}{lrrrr} 
Item & \multicolumn{1}{c}{$\sigma_{\mathrm{p}}^{2}$} & Mean & Minimum & Maximum \\
\hline MYW (kg) & 1487.44 & 436.87 & 316.24 & 562.50 \\
YH (cm) & 12.32 & 126.84 & 111.76 & 137.79 \\
15H (cm) & 13.85 & 128.60 & 113.67 & 142.24 \\
15W (kg) & 2254.74 & 540.93 & 354.26 & 728.02 \\
AP1 (d) & 2001.86 & 283.00 & 168.00 & 471.00 \\
AP3 (d) & 2230.00 & 355.26 & 257.00 & 539.00 \\
SC3 (cm) & 3.62 & 31.59 & 27.00 & 38.50 \\
L3 (cm) & 0.65 & 10.86 & 8.70 & 13.60 \\
V3 (cm $\left.{ }^{3}\right)$ & 6189.84 & 433.67 & 256.30 & 746.40 \\
YSC (cm) & 4.80 & 31.88 & 24.50 & 38.20 \\
15SC (cm) & 5.68 & 34.18 & 26.00 & 40.00 \\
AP (d) & 884.17 & 361.10 & 282.00 & 451.00 \\
PR (0 to 1) & 0.10 & 0.89 & 0.00 & 1.00
\end{tabular}

${ }^{\mathrm{a}} \mathrm{MYW}=$ male yearling $\mathrm{BW} ; \mathrm{YH}=$ yearling height in males; $15 \mathrm{H}=15-\mathrm{mo} \mathrm{BW}$ in males; $15 \mathrm{~W}=15-\mathrm{mo}$ BW in males; AP1 = age at puberty in bulls defined as when a bull produced 50 million sperm with $\geq 10 \%$ progressive motility; AP3, SC3, L3, and $\mathrm{V} 3$ = age, scrotal circumference, height, average testis length, and testis volume when a bull produced 500 million sperm with $\geq 50 \%$ progressive motility; YSC = yearling scrotal circumference; $15 \mathrm{SC}=15$-mo scrotal circumference; $\mathrm{AP}=$ age at puberty for heifers; and PR = pregnancy rate in heifers.
The heritability estimate in Table 5 for YSC (0.05) was considerably less than estimates of 0.68 (dairy bulls), 0.52 , and 0.49 reported, respectively, by Coulter and Foote (1979), Lunstra and Echternkamp (1982), and Bourdon and Brinks (1986), but was similar to an estimate of 0.09 reported by Morris et al. (1992). The heritability estimate (0.37) for 15SC was moderate, but less than the estimate of 0.78 reported by Coulter et al. (1976) for scrotal circumference measured between 12 and 17 mo of age on Holstein bulls. A slightly smaller estimate of 0.32 was reported by Morris et al. (1992) for 15SC. Based on these heritability estimates, 15SC (0.37) should respond more quickly to selection than YSC (0.05). The estimate of genetic correlation of YSC with AP was -0.57 and with PR was 0.35 , but YSC and 15SC were estimated to be highly correlated genetically (1.00).
TABLE 3. Heritability estimates (diagonal) and estimates of genetic correlations (off diagonal) among growth traits ${ }^{\mathrm{a}, \mathrm{b}}$.

\begin{tabular}{lccccrr} 
Trait & MYW & YH & 15W & 15H & AP & \multicolumn{1}{c}{ PR } \\
\hline MYW & 1.00 & 1.00 & 1.00 & 0.21 & 0.00 & 0.49 \\
YH & & 0.20 & 0.58 & 1.00 & 0.66 & -0.48 \\
$15 \mathrm{~W}$ & & & 1.00 & 0.26 & -0.04 & 0.51 \\
$15 \mathrm{H}$ & & & & 0.54 & 0.35 & 0.44
\end{tabular}

${ }^{\mathrm{a}} \mathrm{MYW}=$ male yearling $\mathrm{BW}, \mathrm{YH}=$ yearling height in males, $15 \mathrm{~W}=15-\mathrm{mo} \mathrm{BW}$ in males, $15 \mathrm{H}=15$-mo height in males, $\mathrm{AP}=$ age at puberty in females, and $\mathrm{PR}=$ pregnancy rate in heifers.

${ }^{\mathrm{b}}$ Standard errors of heritability estimates were 0.33 to 0.40 for MYW, $\mathrm{YH}, 15 \mathrm{~W}$, and $15 \mathrm{H}$.
The estimate of genetic correlation of -0.57 between YSC and AP was similar to estimates of -0.71 and -0.76 reported by Brinks et al. (1978) and Morris et al. (1992).

The heritability estimate of 0.10 for heifer PR (Table 5) agreed with the estimates of 0.12 and 0.13 reported, respectively, by Morris et al. (2000) and Evans et al. (1999). The heritability estimate in the present study for heifer $\mathrm{AP}$ of 0.52 generally agreed with estimates of 0.47 and 0.41 reported by Splan et al. (1998) and Laster et al. (1979), respectively. A somewhat greater estimate of 0.61 was reported by MacNeil et al. (1984) using earlier data from GPE. The heritability estimate for heifer PR (0.10) indicates that environmental effects on this trait would make response to direct selection slow, but the heritability estimate for heifer AP (0.52) indicates direct selection would be effective if heritability was that great, although estimates for age at first calving, which is easier to measure, averaged much less (0.06) in the review by Koots et al. (1994).

Estimates of heritability for AP1, average testis length, and testicular volume of $0.47,0.46$ and 0.31 , respectively, were moderate. The heritability estimate for height at puberty in bulls was even greater (0.89). In addition, AP1 was low but positively (favorably) correlated with heifer AP (0.16) and moderately negatively (favorably) correlated with heifer PR $(-0.45)$. The estimates of genetic correlations with SC1 have little meaning because of the near-zero heritability estimate for SC1 for the measure at a relatively young age $($ mean $=283 \mathrm{~d})$. Although SE could not be computed with available software, approximate SE for genetic correlations were large, using the formula of Koots et al. (1994), ranging from 2.55 for small estimates of heritabilities $(0.10)$ and genetic correlation (0.10) to 0.38 for high estimates of heritability (0.50) and a moderate estimate of genetic correlation (0.50).

The expected correlated responses for $\mathrm{AP}$ and $\mathrm{PR}$ in heifers from direct 
TABLE 4. Heritability estimates (diagonal) and estimates of genetic correlations (off diagonal) among fertility traits ${ }^{\mathrm{a}, \mathrm{b}}$.

\begin{tabular}{lcccccccr} 
Trait & AP3 & SC3 & L3 & V3 & W3 & H3 & AP & PR \\
\hline AP3 & \multirow{2}{*}{0.33} & 0.60 & 0.72 & 0.63 & 0.47 & 0.73 & 0.05 & -0.35 \\
SC3 & & 1.00 & 0.76 & 0.97 & 1.00 & 0.64 & -0.23 & -0.97 \\
L3 & & & 0.52 & 0.78 & 1.00 & 0.72 & -0.14 & -0.24 \\
V3 & & & & 1.00 & 0.94 & 0.73 & -0.20 & -0.67 \\
W3 & & & & & 0.34 & 0.57 & -0.08 & 0.17 \\
H3 & & & & & & 0.45 & -0.33 & -0.14
\end{tabular}

${ }^{a}$ AP3 , SC3, L3, V3, W3, and H3 = age, scrotal circumference, average testis length, testicular volume, BW, and height, respectively, when a bull produced 500 million sperm with $\geq 50 \%$ progressive motility; $A P=$ age at puberty in heifers; and $P R=$ pregnancy rate in heifers.

${ }^{\text {b }}$ Standard errors of heritability estimates ranged from 0.32 to 0.42 . selection and from indirect selection on some male growth traits $(\mathrm{YH}$, $15 \mathrm{H}, 15 \mathrm{~W})$ and male reproductive traits (AP1, AP3, SC3, L3, V3, YSC, 15SC) are presented in Table 7 based on estimates of parameters from the limited data of this study. The ratio of expected responses from indirect and direct selection shows which would be expected to be more effective based on the estimates of heritability and genetic correlations from this study. Direct selection for heifer

TABLE 5. Heritability estimates (diagonal) and estimates of genetic correlations (off diagonal) among fertility traits $^{\mathrm{a}, \mathrm{b}}$.

\begin{tabular}{llllr} 
Item & YSC & 15SC & AP & \multicolumn{1}{c}{ PR } \\
\hline YSC & 0.05 & 1.00 & -0.57 & 0.35 \\
$15 S C$ & & 0.37 & -0.06 & 0.00 \\
AP & & & 0.52 & -0.28 \\
PR & & & & 0.10
\end{tabular}

${ }^{\text {aYSC }}=$ yearling scrotal circumference, $15 \mathrm{SC}=15$-mo scrotal circumference, $A P=$ age at puberty in heifers, and $\mathrm{PR}=$ pregnancy rate in heifers.

${ }^{\mathrm{b}}$ Standard errors of heritability estimates were $0.29,0.35,0.12$, and 0.07 , respectively, for YSC, $15 \mathrm{SC}, \mathrm{AP}$, and PR.
$\mathrm{AP}$ would be more effective than indirect selection of males for reproductive or growth traits because of the relatively high heritability estimate for heifer AP. The most favorable male traits for improving female fertility would be scrotal circumference at first freezable semen and $\mathrm{YH}$ and $15 \mathrm{H}$ based on the estimates of the parameters from this study. Although the sample of data was not large, the reason for the advantage of direct selection is the heritability of 0.52 for age at puberty, which was similar to previous estimates. Previous estimates of the advantage for indirect selection based on scrotal circumference were instead for age at first calving, which, in studies summarized by Koots et al. (1994), has a much smaller estimate of heritability (0.06).

Because of the small heritability estimate for PR, selection on many male traits would be expected to be more effective than direct selection because of generally high heritability estimates and favorable estimates of the genetic correlations.

\section{Implications}

Based on estimates of genetic parameters from this set of data, selection of males based on some reproductive and growth traits would be more effective than direct selection to increase PR in heifers. Response to selection using male traits, however, would not be expected to be as effective as direct selection for improving heifer age at puberty in contrast to other studies that have shown that scrotal circumference would be effective for decreasing age at first calving, which has much lower heritability than age at puberty. Estimates of genetic correlations between heifer age at puberty and measures of scrotal circumference in bulls were favorable but small. The estimates of genetic correlations also were favorable between age at puberty in males and females. In addition, response to selection based on heifer age at puberty would not be expected to improve
TABLE 6. Heritability estimates (diagonal) and estimates of genetic correlations (off diagonal) among fertility and growth traits ${ }^{\mathrm{a}, \mathrm{b}}$.

\begin{tabular}{lcccccccr} 
Item & AP1 & SC1 & L1 & V1 & W1 & H1 & AP & PR \\
\hline AP1 & 0.47 & 1.00 & 0.91 & 1.00 & 0.68 & 1.00 & 0.16 & -0.45 \\
SC1 & & 0.00 & 0.78 & 0.97 & 1.00 & 1.00 & 1.00 & -0.75 \\
L1 & & & 0.46 & 0.95 & 1.00 & 0.69 & -0.15 & 0.03 \\
V1 & & & & 0.31 & 1.00 & 1.00 & 0.05 & -0.08 \\
W1 & & & & & 0.49 & 0.82 & 0.01 & -0.11 \\
H1 & & & & & & 0.89 & 0.26 & -0.06
\end{tabular}

${ }^{a} A P 1, S C 1, L 1, V 1, W 1$, and $\mathrm{H} 1$ = age, scrotal circumference, average testis length, testicular volume, BW, and height at puberty in bulls defined as when a bull produced 50 million sperm with $\geq 10 \%$ progressive motility; AP = age at puberty in heifers; $P R=$ pregnancy rate in heifers.

${ }^{\text {b }}$ Standard errors of heritability estimates ranged from 0.23 to 0.36 . 
TABLE 7. Expected correlated responses for age at puberty (AP, days) and pregnancy rate (PR, fraction) in heifers from direct selection and from indirect selection on some male traits $(\Delta)$ with ratio of indirect to direct expected responses $(Q)$ for age at puberty and for pregnancy rate.

\begin{tabular}{lccrrr} 
& \multicolumn{2}{c}{ AP } & \multicolumn{2}{c}{ PR } \\
\cline { 2 - 3 } Item $^{\mathrm{a}}$ & $\boldsymbol{\Delta}$ & $\mathbf{Q}$ & $\boldsymbol{\Delta}$ & Q \\
\hline AP & -7.452 & $(1.00)$ & -0.010 & $(0.63)$ \\
PR & -0.914 & $(0.12)$ & 0.015 & $(1.00)$ \\
AP1 & 2.264 & $(0.30)$ & -0.029 & $(1.93)$ \\
AP3 & 0.593 & $(0.08)$ & -0.019 & $(1.27)$ \\
SC3 & -4.753 & $(0.64)$ & -0.093 & $(6.20)$ \\
L3 & -2.065 & $(0.28)$ & -0.016 & $(1.07)$ \\
V3 & -4.133 & $(0.55)$ & -0.064 & $(4.27)$ \\
YSC & -2.634 & $(0.35)$ & 0.007 & $(0.47)$ \\
15SC & -0.764 & $(0.10)$ & 0.001 & $(0.07)$ \\
YH & 6.100 & $(0.82)$ & -0.030 & $(2.00)$ \\
15H & 5.315 & $(0.71)$ & 0.031 & $(2.07)$ \\
15W & -0.827 & $(0.11)$ & 0.048 & $(3.20)$
\end{tabular}

${ }^{a} A P=$ age at puberty in heifers; $P R=$ pregnancy rate in heifers; $A P 1=$ age at puberty in bulls defined as when a bull produced 50 million sperm with $\geq 10 \%$ progressive motility; AP3, SC3, L3, and V3 = age, scrotal circumference, average testis length, and testicular volume when a bull produced 500 million sperm with $\geq 50 \%$ progressive motility; YSC = yearling scrotal circumference; $15 S C=15$-mo scrotal circumference; $\mathrm{YH}=$ yearling height in males; $15 \mathrm{H}=15$-mo height in males, and $15 \mathrm{~W}=15$-mo BW in males. Correlated responses were calculated assuming selection of approximately $7 \%$ of males and $70 \%$ of females for a 2:1 ratio for the selection intensity factors.

heifer PR. Other studies, with more data, have suggested more favorable genetic responses for some female fertility traits such as age at first calving from indirect selection based on scrotal circumference of males. Male traits, such as scrotal circumference, are also easier and less expensive to measure than female reproductive traits and can be associated with greater selection intensity.

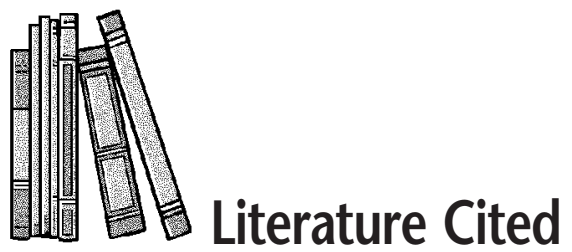

Boldman, K. G., L. A. Kriese, L. D. Van Vleck, C. P. Van Tassell, and S. D. Kachman. 1995. A manual for use of MTDFREML. A set of programs to obtain estimates of variances and covariances. ARS, USDA, Clay Center, NE.

Bourdon, R. M., and J. S. Brinks. 1986. Scrotal circumference in yearling Hereford bulls: Adjustment factors, heritabilities and genetic, environmental and phenotypic relationships with growth traits. J. Anim. Sci. 62:958.

Brinks, J. S., M. J. McInerney, and P. J. Chenoweth. 1978. Relationship of age at puberty in heifers to reproductive traits in young bulls. Proc. West. Sect. Am. Soc. Anim. Sci. 29:28.

Coulter, G. H., T. R. Rounsaville, and R. H. Foote. 1976. Heritability of testicular size and consistency in Holstein bulls. J. Anim. Sci. 43:9.

Coulter, G. H., and R. H. Foote. 1979. Bovine testicular measurements as indicators of reproductive performance and their relationship to productive traits in cattle: A review. Theriogenology 11:297.

Doyle, S. P., B. L. Golden, R. D. Green, and J. S. Brinks. 2000. Additive genetic parameter es- timates for heifer pregnancy and subsequent reproduction in Angus females. J. Anim. Sci. 78:2091.

Evans, J. L., B. L. Golden, R. M. Bourdon, and K. L. Long. 1999. Additive genetic relationship between heifer pregnancy and scrotal circumference in Hereford cattle. J. Anim. Sci. $77: 2621$.

Falconer, D. S., and T. F. C. Mackay. 1996. Introduction to Quantitative Genetics. (4th Ed.). Longman, Essex.

Koots, K. R., J. P. Gibson, and J. W. Wilton. 1994. Analyses of published genetic parameter estimates for beef production traits. 2. Phenotypic and genetic correlations. Anim. Breed. Abstr. 62:825.

Laster, D. B., G. M. Smith, L. V. Cundiff, and K. E. Gregory. 1979. Characterization of biological types of cattle (cycle II) II. Postweaning growth and puberty of heifers. J. Anim. Sci. 48:500.

Lunstra, D. D., J. J. Ford, and S. E. Echternkamp. 1978. Puberty in beef bulls: Hormone concentrations, growth, testicular development, sperm production and sexual aggressiveness in bulls of different breeds. J. Anim. Sci. 46:1054.

Lunstra, D. D., and S. E. Echternkamp. 1982. Puberty in beef bulls: Acrosome morphology and semen quality in bulls of different breeds. J. Anim. Sci. 55:638.

Lunstra, D. D., J. D. Crouse, and L. V. Cundiff. 1993. In Puberty Occurs at the Same Testis Size in both Bos taurus and Bos indicus Crossbred Beef Bulls. USDA ARS-71 RLHUSMARC Beef Cattle Research Program, Progress Report No. 4. p 90. USDA, Clay Center, NE.

MacNeil, M. D., L. V. Cundiff, C. A. Dinkel, and R. M. Koch. 1984. Genetic correlations among sex-limited traits in beef cattle. J. Anim. Sci. 58:1171.

Morris, C. A., R. L. Baker, and N. G. Cullen 1992. Genetic correlations between pubertal traits in bulls and heifers. Livest. Prod. Sci. $31: 221$.

Morris, C. A., J. A. Wilson, G. L. Bennett, N. U. Cullen, S. M. Hickey, and J. C. Hunter. 2000. Genetic parameters for growth, puberty, and beef cow reproductive traits in a puberty selection experiment. New Zealand J. Agric. Res. 43:83.

Splan, R. K., L. V. Cundiff, and L. D. Van Vleck. 1998. Genetic parameters for sex-specific traits in beef cattle. J. Anim. Sci. 76:2272.

Toelle, V. D., and O. W. Robison. 1985. Estimates of genetic correlations between testicular measurements and female reproductive traits in cattle. J. Anim. Sci. 60:89. 